\title{
COMPARATIVE STUDY OF LIBERALIZATION PROCESS OF PASSENGERS RAILWAY MARKET IN SPAIN AND ENGLAND
}

\author{
Graciela Fernández Morote \\ Transport Planning Engineer, WSP/Parsons Brinckerhoff, United Kingdom \\ Armando Ortuño Padilla \\ Associate professor, Building and Urbanism Department, University of Alicante, Spain \\ Patricia Fernández Aracil \\ $\mathrm{PhD}$ student and researcher, University of Alicante, Spain
}

\section{SUMMARY}

This article provides an overview of the privatization of railway passengers market in Spain through a background to the most relevant cases studies in Europe, particularly the liberalization process in England. The English case study is a paradigmatic example to assess how the liberalization process was developed and its effect in the present. This assessment has been undertaken to analyse the railway franchise structure, ticketing measures, role of national and regional authorities, etc. and possible analogies to be adapted to the case of Spain.

Firstly, this article reviews the origin of the privatization of the railway market in both Spain and England, describing every phase of the liberalization and the success of every stage. Secondly, a critical approach assessment exposes those market failures of the liberalization process in England that caused negative impacts on society. In addition, the role of the Government is analysed to measure their implication in order to solve that situation. Furthermore, the paper expounds a wide analysis of the rail ticketing in England, its effects on increased passenger number.

Finally, this article proposes some measures to be followed on the privatization of passenger rail market in Spain, as well as some key concepts to guarantee its success as taken from the case studies that have been reviewed.

\section{INTRODUCTION}

Railway passengers' liberalization process in Spain started with the Real Decreto-ley $22 / 2012$ of $20^{\text {th }}$ July. This law established proposals about infrastructure and railway services to be implemented as an initial date the $31^{\text {st }}$ July 2013. On the one hand, the English Railway Act come up in 1993 and the liberalization passenger railway process started in United Kingdom. This temporal gap between both processes in Spain and United Kingdom implies that the English case became as a paradigmatic case study for the Spanish one. The English historical experience in railway passenger's privatisation allows its comparative study for 
Spain and, as a consequence, a learning example of its effects and consequences in the railway market.

According to this statement, the aim of this research is to highlight those proposals made in United Kingdom that could be potential successful in the railway privatization system in Spain. In addition, the object it to prevent market failures or negative economic impacts in the market associated with the following factors: phases, structural organized market, ticketing regularization and the origin of different bodies and administrations.

\section{THE PASSENGER RAIL PRIVATISATION IN UNITED KINGDOM AND KEY BODIES}

Whereas in the past, transport was generally perceived as an industry that required Government control and supervision, since 1980, the neoliberal philosophy prioritizes market forces and the transport industry in England has been regarded as an ideal candidate for privatization and deregulation (Gibb et al., 1996). The 1993 Railway Act reached its highest point with the rail privatisation and the services were franchised to the private sector between

February 1996 and March 1997 (Preston and Robins, 2013). The first element of privatisation was that passenger operations were horizontally separated into 25 Train Operating Companies (TOC) and a model of off-the-track competition was introduced to be administered by the Office of Passenger Rail Franchising (OPRAF). Only five of that TOC are currently on the business: Arriva, First, Go-Ahead, National Express and Stagecoach.

The OPRAF were operating contracts and penalizations with prescriptive and relatively short contracts between 7 and 15 years. However, OPRAF after a deterioration was replace by the creation of the Strategic Rail Authority (SRA) which was abolished in 2006 as a result rail operation were brought under the direct control of the Department for Transport (DfT) of English Government.

The Office of Rail Regulation (ORR) was established to regulate Railtrack and ensure fair track access charges and became responsible for safety regulation and guarantees the efficiency and economy for railway passenger services. The track and other rolling stock equipment for the passenger services were supplied by the Rolling Stock Operating Company which had the function of infrastructure maintenance and renewal and rolling stock maintenance that were leased to TOC.

In the meantime, the rail business was vertically segregated, with operations split from infrastructure, being Railtrack the main owner of this such as monopolies railway management. The TOC should have paid to Railtrack the access charges to the infrastructure. After Railtrack decadences in 2001, which reasons will be explained later, Network Rail were the supplier of the railway infrastructure. Fig. 1 shows the general structure of all main actors involved and the relationships between each other. 


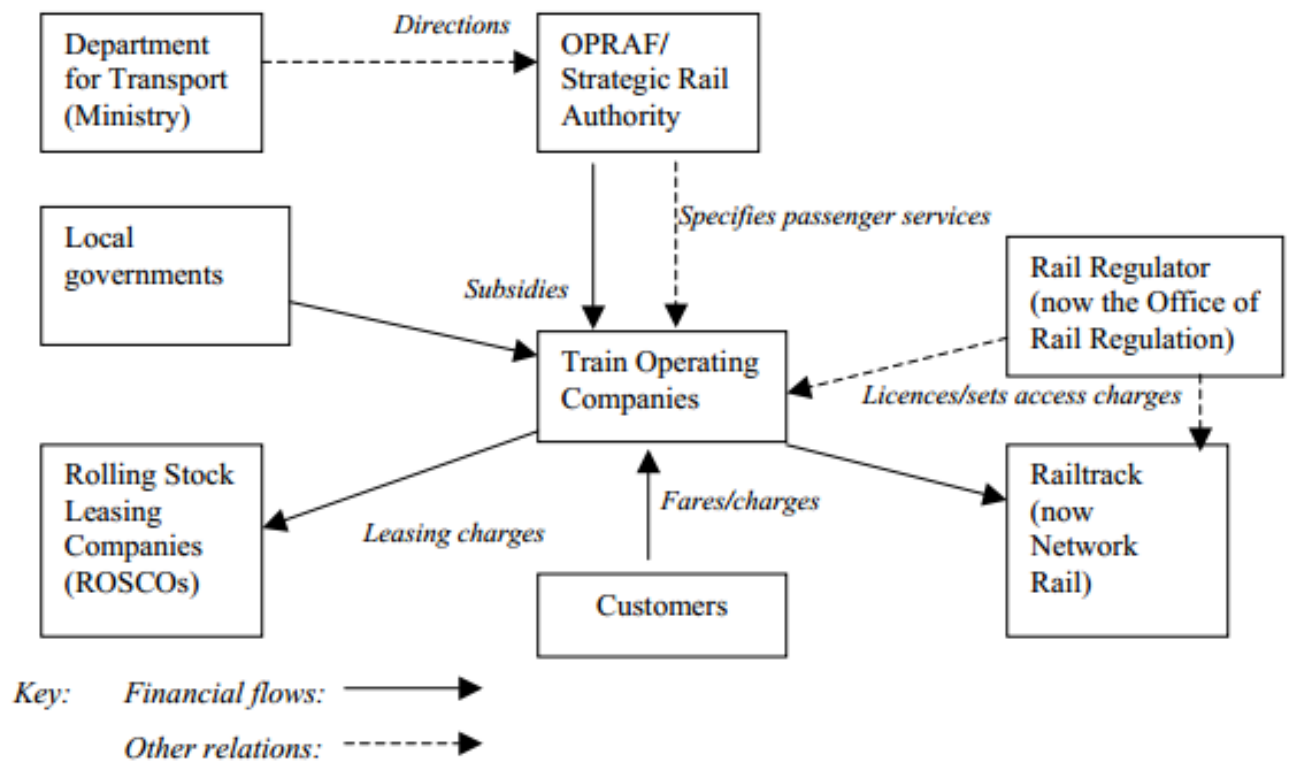

Fig. 1 - The Privatised Structure 1996- 2005 in United Kingdom (Drew, 2006)

\section{THE PASSENGER RAIL PRIVATISATION IN SPAIN}

Different possibilities of railway system liberalization could be outlined by three general restructuring models (Gómez-Ibáñez, 2006):

a) Vertical disintegration: this model requires at least a split between the transport services and infrastructure management. The aim is to allow a progressive access of other operator, private and public, to competition. This model has been adopted basically in the European Union.

b) Privatization: consist on introducing private sector participation, completely or partial, through concessions between 10 and 50 years. This model has been applied in different countries as Japan, Mexico, Brazil or Argentina. This model is always accompanied by closing lines or land design restructure, trying to show more attractive appearance to investors.

c) Deregulation: this model consist on a liberalization of the railway regulation, particularly those refers to charges and railway business access. This model has been applied in countries such as EEUU, Canada or Switzerland. Although its effects was more significant on Logistics market rather than interurban passengers services.

Focusing our attention in the Spanish case study, this case would represent a vertical Split combining with privatization. This case has its origin in the European Railway Legislation, which aim is to improve the decline railway sector after the publication of the Transport White Paper in 1979. At that time the Directive 1991/440 established the bases to open the railway market in Europe, afterwards different sections of policies were published (Campos, 2006). The formal transposition of that was being undertaken from Europe through the Railway Act 39/2003 of $17^{\text {th }}$ November called Ley del Sector Ferroviario (LSF). This law established the liberalization of railway goods transport at the end of 2005, as the start of a 
new Railway Infrastructure Management Body or Administrador de Infraestructuras Ferroviarias (ADIF).

However, the opening of the national railway passengers competition began with the Real Decreto Ley $22 / 2012$ of $30^{\text {th }}$ July. This law allowed defining policies and regulation related to railway infrastructure and passengers services and established the $32^{\text {st }}$ July 2013 as a date to start the transition between the current monopolist renfe and the future liberalization market, distinguishing the business in these three following segments:

a) Passengers servicing focus on Tourist activity, this business is currently free to competition since $31^{\text {st }}$ July 2013 through the Policy FOM/1403/2013, of $19^{\text {th }}$ July about railway passengers' transport with tourist objective primarily.

b) Commercial railway services (long distance and high speed railway), which transition to liberalization is on progress.

c) Public services obligations (interurban and long distance) which service will be ensured by renfe.

Commercial railway services will be undertaken through operating licences. This system will allow offering passenger railway services to private operator across the Levante Corridor, in some of lines during a period of time of 7 years and will be published to public competition. After a certain period of time applications for open access will be offered across the Corridor. Then, new operators could establish their own frequencies, timetables and number of services, ticketing costs and use the railway infrastructure which rent will be offered by renfe-Sociedad de Alquiler de Material Ferroviario.

Recently, after the new LSF (Ley 38/2015, 29th September), some new changes have been included such as: the advertising of railway infrastructure action plan and next 5 years charges; new system to guarantee fair track access charges or abolition of excess and access charges that it acted as an access barrier. In addition, railway operator will contribute providing information about their activity and finances to guarantee transparency.

Currently, a reform about opening to some of high speed rail corridors will be undertaken in the following moths. Although some recommendations made by Tribunal de Cuentas (2015) should be considered:

a) Limit loss-making investment, giving priority to socio-economic evaluation assessment of projects;

b) Avoid subsidise from public resources in the liberalization system, it is highly recommended a review about the access charge to satisfied the cost of the network;

c) Spanish double railway model, which is split between the railway infrastructure body and the operating transport services, makes much more difficult to evaluate the global economic feasibility of the railway management services. Therefore, it is needed to adopt some changes to improve better transparency. 


\section{MARKET FAILURES OF LIBERALIZED RAILWAY TRANSPORT}

According to United Kingdom experience, Crompton and Jupe (2003) consider that the liberalization process happened as fail, due to it did not achieve the three main benefits expected to occur: better efficiency, better quality for passengers and a reduction on public subsidies. An integrated Britain's Railways (BR), with the most financially successful railway in Europe (Crompton y Jupe, 2003), was broken up to create a very complex, fragmented industry without parallel anywhere (Nash, 2000).

The $17^{\text {th }}$ October 2000, a dramatic accident occurred in Hatfield, located 30km north London which was caused by serious shortcomings in track maintenance procedures and lack of speed restrictions. This accident, which resulted on 4 fatal victims and 70 serious ones, was a key fact in the liberalisation process and the way of managing the infrastructure; this led to increase the investments to the infrastructure as well as compensation to the TOC, which finished in the Railtrack's insolvency.

Focusing on the Railtrack, as a result of this accident, the Central Government created a subsidised society and controlled by the Department for Transport (DftT). The collapse of Railtrack revealed fatal flaws in the privatisation model, flaws which had been concealed in the short run by Railtrack's generous treatment while it focused on profit maximisation rather than infrastructure maintenance and renewal (Crompton y Jupe, 2003).

After the negative experiences in United Kingdom during privatization in the 1990s, no other country has privatized its tracks or stations (Beckers et al., 2009).

\section{IMPACT OF THE RAILWAY ACCESS CHARGES POLICY}

As it is shown in Department for Transport y ORR (2011), the charges structure is a key point in the railway system due to its relationship with passengers demand. According to this, it is observed after privatisation, demand of passengers increased as much as the ticketing costs did. This tendency has been continued during several decades in the railway services in United Kingdom, however caused by different reasons (Nash y Smith, 2006), such as: economic improvement, road congestion and price of oil.

According to Bowman (2015), while the high number of passengers supported a successfully history of private companies, the financial assessment of the Network Rail was completely different due to the significant increase of the debt that was assumed by this body to make improvements on the network.

Surprisingly, comparing average costs of the railway passengers tickets among United Kingdom and other European countries, these prices are relatively high (Fig. 2): taken into account the price in United Kingdom per kilometre, this is $50 \%$ higher than the average costs in France, Germany, Italy and Spain (Bowman et al., 2013). 


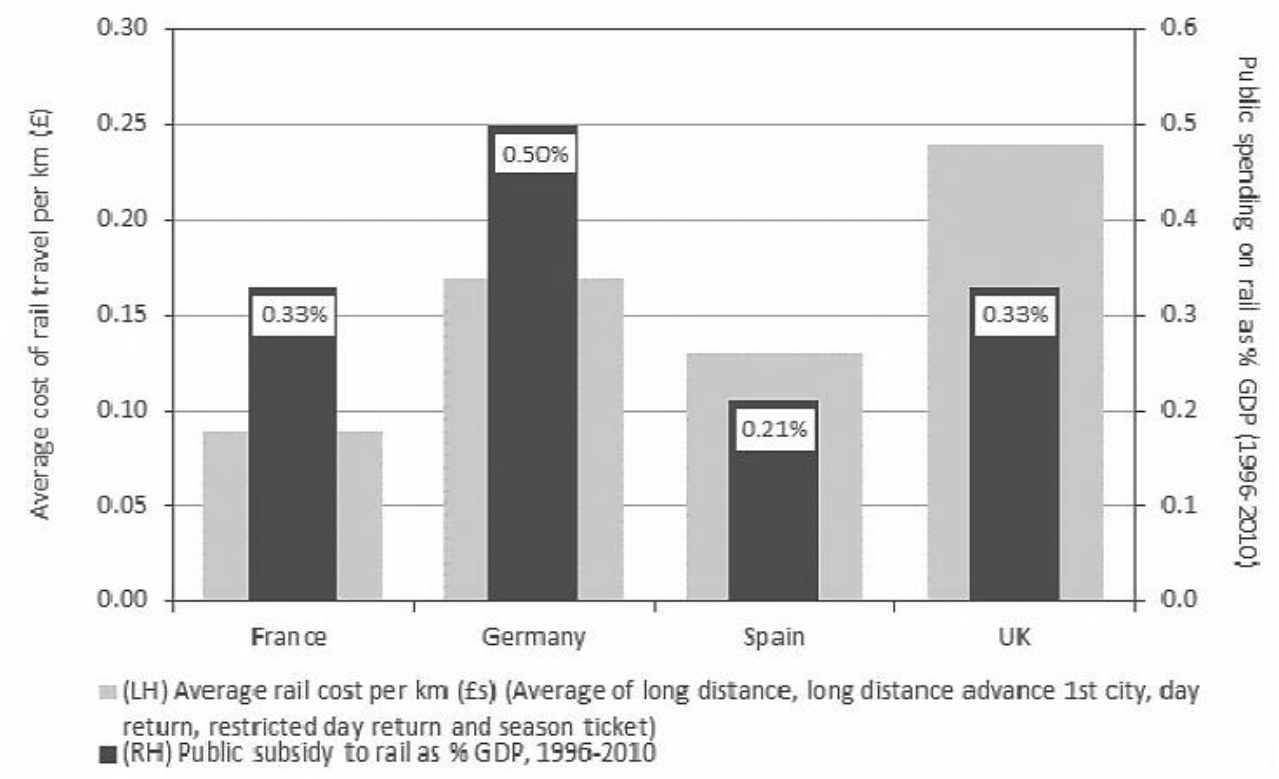

Fig. 2 - Public subsidy to rail vs. average cost of rail travel for UK vs. major EU economies (Bowman et al., 2013)

Comparing United Kingdom with Germany, it is reasonable to think that low prices in the second case could be consequence of high public subsidy that the railway sector receives. However, in France, with the same ratio of public subsidy, the average cost of rail travel per kilometre is much lower than in United Kingdom. Preston (2009) thinks that the increase of long distance prices was caused by improvements in the management maintenance techniques since Hatfield accident.

Glaister (2004), compare the role of Government in the regulation of Railway Systems with the liberalization of others British sectors. While in other industries the role of Government is focus on giving access to the operators, in railway sector the main object is the economic regulation and establish track access charges. Glaister (2004) highlights that these charges regulation is made though TOC's contracts, which have a direct implication on public spending and, therefore, in Government expenditure.

\section{CONCLUSION}

Two main conclusions could be reached from this paper: in the first place, Government actions in the English case study was not enough, due to the unique benefit obtained was the increase in passenger number, fact that could have been caused by other different factors; in the second place, the implementation of a right and fair regulation of the track access charge is essential to demand management and public deficit control.

Consequently, the lesson learnt for Spanish case can be summarized basically in two recommendations: the first one, the split in the provision if a public service nationally cannot be a synonym of improvement; the second one, even there are different theories that try to 
mitigate market fail, in the case of railway transport the experience shows that the direct intervention of Government is essential to guarantee the benefit of society. According to this point, the initial position of Spanish Government in the infrastructure railway management, must be positive, due to ADIF is a public body which will not be liberalized.

It is worth to be mentioned, that the possibilities of a success in the liberalization of Spanish market are considered limited, taken into account the broad differences between the rail passengers demand between England (much higher) and Spain. What it is more, if the resulting path allocation possibilities and frequencies of the liberalised routes remain unchanged by public operator, private operators may have little room for manoeuvre.

\section{ACKNOWLEDGEMENTS}

The authors are grateful to the support from the Office of the Vice President for Research, Development and Innovation of University of Alicante within Programa Propio to encourage R\&D\&I, which beneficiary is the co-author Patricia Fernández Aracil.

\section{REFERENCES}

BECKERS, T., HIRSCHHAUSEN, C., HAUNERLAND. F., and WALTER, M. (2009). Long-Distance Passenger Rail Services in Europe: Market Access Models and Implications for Germany. International Transport Forum, Madrid.

BOWMAN, A., FOLKMAN, P., FROUD, J., JOHAL, S., LAW, J., LEAVER, A., MORAN, M. and WILLIAMS, K. (2013). The great train robbery: rail privatisation and after. Centre for Research on Socio-Cultural Change (CRESC), Manchester, pp. 1-167.

BOWMAN, A. (2015). An illusion of success: The consequences of British rail privatisation. Accounting Forum, 39, pp. 51-63.

CAMPOS, J. (2015). La competencia en el ferrocarril: un análisis del nuevo marco institucional en Europa y en España. Fedea Policy Papers, 2015/12, pp. 12-19.

CROMPTON, G. and JUPE, R. (2003). Such a silly scheme: The privatisation of Britain's Railways 1992-2002. Critical Perspectives on Accounting, 14, pp. 617-645.

DEPARTMENT FOR TRANSPORT and OFFICE OF RAIL REGULATION (ORR). (2011). Realising the Potential of GB Rail. Final Independent Report of Rail Value for Money Study.

DREW, J. (2006). Rail Freight: the Benefits and Costs of Vertical Separation and Open Access. Association for European Transport Conference.

GIBB, R., LOWNDES, T. and CHARLTON, C. (1996). The privatization of British Rail. Applied Geography, 16(1), pp. 35-51.

GLAISTER, S. (2004). British rail privatisation: Competition destroyed by politics. University of Bath School of Management, Bath, Occasional Paper 23.

GÓMEZ-IBÁÑEZ, J. A. (2006). An overview of the options. En: J.A. GÓMEZ-IBÁÑNEZ y 
G. de RUS (eds.), Competition in the railway industry. An international comparative analysis. Edward Elgar, Cheltenham, pp. 1-24.

KNOWLES, R.D. (2004). Impacts of privatising Britain's rail passenger services franchising, refranchising, and Ten Year Transport Plan targets. Environment and Planning, 36(11), pp. 2065-2087.

NASH, C. A. (2000). Privatization and Deregulation in Railways: An Assessment of the British Approach. En: B. BRADSHAW y H. LAWTON SMITH (eds.), Privatization and Deregulation of Transport. Macmillan Press Ltd., London, pp. 159-176.

NASH, C.A. and SMITH, A.S.J. (2006). Passenger rail franchising: British experience. ECMT Workshop on Competitive Tendering for Passenger Rail Services, Paris.

PRESTON, J.M. (2009). Competition for long distance passenger rail services: The emerging evidence. 18th International Symposium on Transport Economics and Policy, Madrid.

PRESTON, J. and ROBINS, D. (2013). Evaluating the long term impacts of transport policy: the case of passenger rail privatisation. Research in Transportation Economics, 39, pp. 1420.

TRIBUNAL DE CUENTAS. (2015). Nº 1090 Informe de fiscalización de la financiación de las infraestructuras ferroviarias en el período 2011-2013. 


\title{
ESTUDIO COMPARATIVO DEL PROCESO DE LIBERALIZACIÓN DEL TRANSPORTE FERROVIARIO DE PASAJEROS EN ESPAÑA Y REINO UNIDO
}

\author{
Graciela Fernández Morote \\ Planificación del transporte, WSP/Parsons Brinckerhoff, Reino Unido \\ Armando Ortuño Padilla \\ Profesor contratado doctor, Universidad de Alicante, España \\ Patricia Fernández Aracil \\ Investigadora predoctoral, Universidad de Alicante, España
}

\section{RESUMEN}

En esta ponencia se aborda el proceso de liberalización del transporte ferroviario de pasajeros en España a partir de la perspectiva histórica acontecida en otros países europeos, haciendo especial hincapié en el proceso liberalizador llevado a cabo en Reino Unido. El caso inglés es considerado como paradigmático y clarificador en determinadas cuestiones de cara a evaluar el proceso que se está siguiendo en España: estructura organizativa del mercado, políticas tarifarias, naturaleza de los entes implicados, agentes intervinientes, etc. En primer lugar, se ahonda en el origen de los procesos de privatización en ambos países, desglosando cada una de las fases acontecidas a lo largo del avance en el camino hacia la liberalización, resultando parcial en algunos casos y total en otros.

En segundo lugar, se exponen con detenimiento los fallos de mercado detectados en la liberalización ferroviaria inglesa — causantes, en algunos casos, de serios perjuicios para la sociedad-, así como las soluciones aportadas, discutiendo su grado de idoneidad. Seguidamente, se explica el efecto de las políticas tarifarias en Reino Unido, además de su impacto sobre el crecimiento de viajeros.

Por último, se esbozan aquellas pautas entendidas como apropiadas para llevar a cabo el proceso liberalizador en España derivadas del aprendizaje histórico de los casos análogos estudiados.

\section{INTRODUCCIÓN}

El proceso de liberalización del transporte ferroviario de pasajeros en España se inició con el Real Decreto-ley 22/2012, de 20 de julio, por el que se adoptan medidas en materia de infraestructuras y servicios ferroviarios, que estableció como fecha de partida para el mismo el 31 de julio de 2013. Por otro lado, la Ley Ferroviaria inglesa de 1993 inició el proceso de privatización de los servicios ferroviarios en Reino Unido. Este lapso temporal existente entre ambos procesos implica que el caso de Reino Unido se acontezca como paradigmático para el análogo español, pues la experiencia histórica del primero facilita su estudio 
comparativo, con el consecuente aprendizaje para el segundo.

Por este motivo, la presente investigación trata de arrojar luz sobre aquellas pautas entendidas como más apropiadas para llevar a cabo el proceso liberalizador en España con el objetivo de evitar fallos de mercado o impactos económico-financieros negativos atendiendo a un conjunto de factores, tales como: las fases, la estructura organizativa del mercado, las políticas tarifarias, la naturaleza de los entes implicados o los agentes intervinientes.

\section{LA LIBERALIZACIÓN DEL TRANSPORTE FERROVIARIO EN REINO UNIDO Y ACTORES IMPLICADOS}

Mientras que en el pasado el transporte se percibía generalmente como una industria que requiere la supervisión y el control por parte del gobierno, desde 1980, la industria del transporte ha sido considerada en Inglaterra como una candidata ideal para su privatización y desregulación, pensamiento respaldado por la filosofía neoliberal que prioriza las fuerzas de mercado (Gibb et al., 1996). La Ley Ferroviaria (Railways Act) de 1993 culminó con la privatización del sistema ferroviario, cuyos primeros cambios organizativos fueron implementados entre febrero de 1996 y marzo de 1997 (Preston y Robins, 2013). La primera de las acciones llevadas a cabo fue la segregación horizontal de la empresa pública operadora de transporte ferroviario en 25 empresas privadas - de las cuales actualmente sólo resisten 5: Arriva, First, Go-Ahead, National Express y Stagecoach - operadoras de transporte de pasajeros (Train Operating Companies, en adelante, TOC) que, a partir de entonces quedarían administradas por la Oficina de Concesiones de Ferrocarril de Pasajeros (Office of Passenger Rail Franchising, en adelante, OPRAF). La OPRAF operaba en un régimen de incentivos y penalizaciones, adjudicando concesiones por periodos comprendidos entre $7 \mathrm{y}$ 15 años; sin embargo, quedaría reemplazada más tarde, en 2001, por la Autoridad Ferroviaria Estratégica (Strategic Rail Authority, en adelante, SRA), la cual, a su vez, fue abolida en 2006, con sus funciones transferidas al Departamento de Transportes (Department for Transport) del Gobierno de Inglaterra.

El proceso de licitación estaba moderado por la Oficina de Regulación del Ferrocarril (Office of Rail Regulation, en adelante, ORR), encargada de proteger los intereses de los usuarios del ferrocarril a través de garantizar la competencia, la eficiencia y la economía en la prestación de los servicios ferroviarios.La maquinaria y los equipos mecánicos necesarios para el transporte ferroviario de pasajeros eran proporcionados por las empresas operadoras de material rodante (Rolling Stock Operating Company, en adelante, ROSCO), encargadas de reponer y mantener el material rodante, que se alquilaba a las TOC.

Por otro lado, la privatización de la infraestructura ferroviaria se llevó a cabo mediante segregación vertical, siendo el ente propietario y encargado de su gestión monopolística Railtrack. Las TOC debían pagar a Railtrack el correspondiente canon de acceso por el uso de la infraestructura. Tras el declive de Railtrack en 2001, por razones que se explicarán más 
adelante, Network Rail se convirtió en la compañía proveedora de infraestructura ferroviaria.

El esquema general de todos los actores implicados y sus relaciones se expone en la Fig. 1:

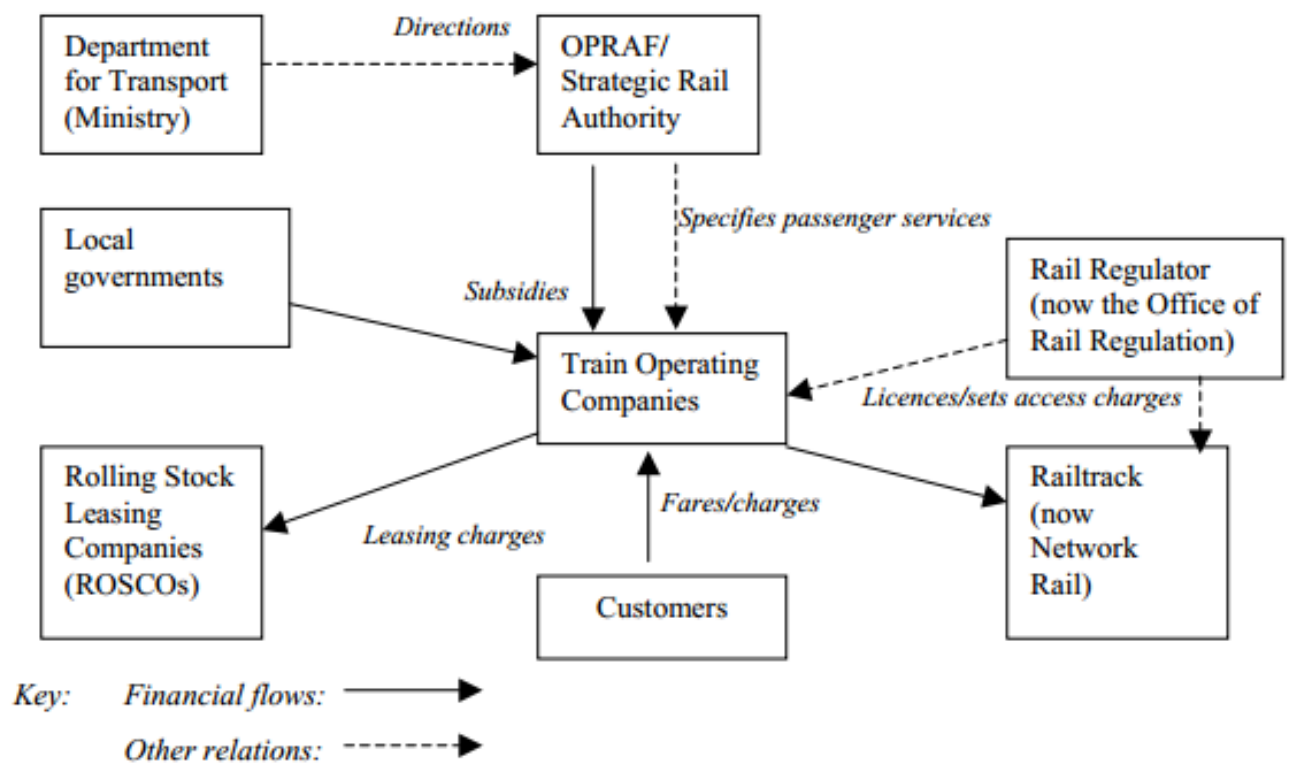

Fig. 1 - Configuración de los actores implicados en la gestión del sistema ferroviario en Reino Unido (Drew, 2006)

\section{LA LIBERALIZACIÓN DEL TRANSPORTE FERROVIARIO EN ESPAÑA}

Las posibilidades de liberalización del transporte ferroviario pueden atender a tres modelos generales de reestructuración (Gómez-Ibáñez, 2006):

d) Desintegración vertical: requiere la segregación, como mínimo a nivel contable, entre los servicios de transporte y la gestión de sus infraestructuras. El objetivo es permitir el acceso progresivo de otros operadores a competir, tanto públicos como privados. Este modelo ha sido el adoptado mayoritariamente en la Unión Europea.

e) Privatización: consiste en la introducción de participación privada, bien de forma completa, o bien parcial, mediante concesiones de entre 10 y 50 años. Este modelo ha sido aplicado en países como Japón, México, Brasil o Argentina, siempre acompañado por una reorganización de los servicios, como el cierre definitivo de líneas poco rentables o la reestructuración territorial, con la finalidad de de hacer del ferrocarril un negocio más atractivo para los potenciales inversores privados.

f) Desregulación: consiste en liberalizar la regulación ferroviaria, particularmente en lo referente a las tarifas y a las condiciones de acceso al mercado. Este modelo ha sido aplicado en países como EEUU, Canadá o Suiza, aunque su efecto fue más significativo en el transporte de mercancías y los servicios interurbanos de pasajeros.

Centrando ahora la atención en el caso español, que respondería a un caso de desintegración vertical combinada con privatización, éste tiene su origen en la legislación ferroviaria comunitaria, que trata de dar respuesta explícita al declive del sector desde la publicación 
del Libro Blanco del Transporte de 1979, siendo la Directiva 1991/440 aquella que establece las bases para la apertura del mercado ferroviario en Europa, seguida de diversos paquetes ferroviarios comunitarios (Campos, 2006). La trasposición formal de aquello que se venía promulgando desde Europa se lleva a cabo por medio de la Ley 39/2003, de 17 de noviembre, del Sector Ferroviario (LSF, en adelante) que suponía la liberalización del mercado de transporte de mercancías por ferrocarril a finales de 2005, así como la puesta en marcha del Administrador de Infraestructuras Ferroviarias (ADIF).

Sin embargo, el proceso de apertura a la competencia del tráfico nacional de viajeros por ferrocarril se inició con el Real Decreto Ley 22/2012, de 20 de julio, por el que se adoptan medidas en materia de infraestructuras y servicios ferroviarios y que estableció como fecha de partida para dar comienzo a la transición entre el monopolio actual de renfe y el futuro marco liberalizado el mismo el 31 de julio de 2013, distinguiendo entre tres segmentos de mercado:

d) Servicios de finalidad prioritariamente turística, que actualmente se encuentran plenamente abiertos a competencia desde 31 de julio de 2013, a través de la Orden FOM/1403/2013, de 19 de julio, sobre servicios de transporte ferroviario de viajeros con finalidad prioritariamente turística.

e) Servicios comerciales (larga distancia convencional y de alta velocidad), cuya transición hacia la liberalización está puesta en marcha.

f) Servicios con obligaciones de servicio público (cercanías y media distancia), cuya prestación se garantiza por renfe.

La liberalización de los servicios comerciales se realizará mediante títulos habilitantes, que permitirán al operador privado prestar servicios ferroviarios de viajeros en el Corredor Levante, en unas determinadas líneas y durante un periodo de 7 años, y se conceden mediante un procedimiento público de licitación. Tras este plazo, el corredor se abrirá a la plena competencia. El nuevo operador podrá determinar libremente tanto las frecuencias de sus servicios, como los precios, así como hacer uso del material rodante puesto en alquiler por renfe-Sociedad de Alquiler de Material Ferroviario.

Recientemente, con la entrada en vigor de la nueva LSF (Ley 38/2015, de 29 de septiembre), algunas novedades han sido introducidas: la publicación de la previsión de actuaciones a realizar en materia de infraestructura, así como de los cánones durante los próximos 5 años; la creación de un nuevo sistema de cánones que incentive el uso de la infraestructura; la eliminación del canon de acceso, que suponía una barrera de entrada; o la aportación, por parte de los operadores ferroviarios, de información de actividad y contable para garantizar la transparencia del mercado.

Actualmente, se encuentra en marcha una reforma que abrirá en los próximos meses algunos corredores de alta velocidad a la entrada de operadores privados, sin embargo, cabe tener presentes algunas de las recomendaciones propuestas por el Tribunal de Cuentas (2015): 
d) Limitar las inversiones altamente deficitarias, priorizando la evaluación socioeconómica de proyectos.

e) Ante la apertura del proceso liberalizador, evitar que se subvencione con recursos públicos actividades del sector privado, por lo que sería conveniente revisar el sistema de cánones ferroviarios a fin de que sean suficientes para cubrir los costes de la red.

f) El modelo dual español, que separa la administración de la infraestructura de la prestación de los servicios de transporte, dificulta la evaluación de la viabilidad económica global la gestión de la explotación de la red ferroviaria, por lo que es preciso adoptar medidas con el objetivo de lograr una mayor transparencia.

\section{LOS FALLOS DE MERCADO DEL TRANSPORTE FERROVIARIO LIBERALIZADO}

Basándonos en la experiencia de Reino Unido, Crompton y Jupe (2003) consideran el proceso liberalizador allí acontecido como fallido, debido a que no logró sus tres beneficios principales previstos: mayor eficiencia, mejora de la calidad para los consumidores y reducción del nivel de subsidio público. Britain's Railways pasó de ser una entidad integrada y única, con la financiación del sistema de ferrocarril más exitosa de Europa (Crompton y Jupe, 2003), a una compleja estructura fragmentada sin parangón en el mundo (Nash, 2000).

El 17 de octubre del año 2000, tuvo lugar un trágico descarrilamiento sucedió en Hatfield, situado a $30 \mathrm{~km}$ al norte de Londres y provocado por el mal estado de la vía y por la ausencia de una limitación de velocidad. Este hecho supuso un punto de inflexión en el proceso de privatización y en el modo de gestionar la infraestructura, causando 4 víctimas mortales y 70 heridos. Después del accidente de Hatfield, aumentaron las inversiones en la infraestructura, así como la compensación para las TOC, factores que llevaron a Railtrack a la insolvencia (Knowles, 2004).

Con el fin de Railtrack, el gobierno central optó por crear una sociedad limitada por garantía y sin accionistas, aunque subsidiada por el gobierno. El colapso de la Railtrack reveló los fallos de mercado que había originado la privatización, aunque escondidos en el corto plazo, pues su objetivo se centraba en la maximización del beneficio en lugar de mantenimiento de la infraestructura y su renovación (Crompton y Jupe, 2003). Después de las negativas experiencias en Reino Unido durante el proceso de privatización, ningún otro país ha privatizado la infraestructura ni las estaciones de tren (Beckers et al., 2009).

\section{IMPACTO DE LAS POLÍTICAS TARIFARIAS EN EL TRANSPORTE FERROVIARIO}

Como se explica en Department for Transport y ORR (2011), la estructura de las tarifas es un elemento clave en el sistema ferroviario ya que se encuentra estrechamente relacionado con la demanda de pasajeros. En ese sentido, se observa cómo, después de la privatización, la demanda de pasajeros incrementó tanto como las tarifas ferroviarias, tendencia que se ha 
seguido manteniendo durante varias décadas en el servicio ferroviario de Reino Unido, sin embargo, estos incrementos pueden atender a diferentes razones (Nash y Smith, 2006), como son: el crecimiento de la economía, la congestión en las carreteras o el precio del petróleo.

Según Bowman (2015), mientras que los datos sobre el número de pasajeros respaldan una historia de éxito de la mano de la empresa privada, las cuentas de Network Rail cuentan otra totalmente diferente, debido al crecimiento significativo de la carga de la deuda asumida por gestor de la infraestructura para financiar mejoras de infraestructura.

Paradójicamente, al comparar el coste medio de los títulos de transporte en Reino Unido con otros países europeos, éstos resultan relativamente altos (Fig. 2): considerando los trayectos de larga distancia, los billetes de ida y vuelta y los abonos, los precios en Reino Unido por kilómetro son alrededor de dos veces mayores que la media de los mismos en Francia, Alemania, Italia y España (Bowman et al., 2013).

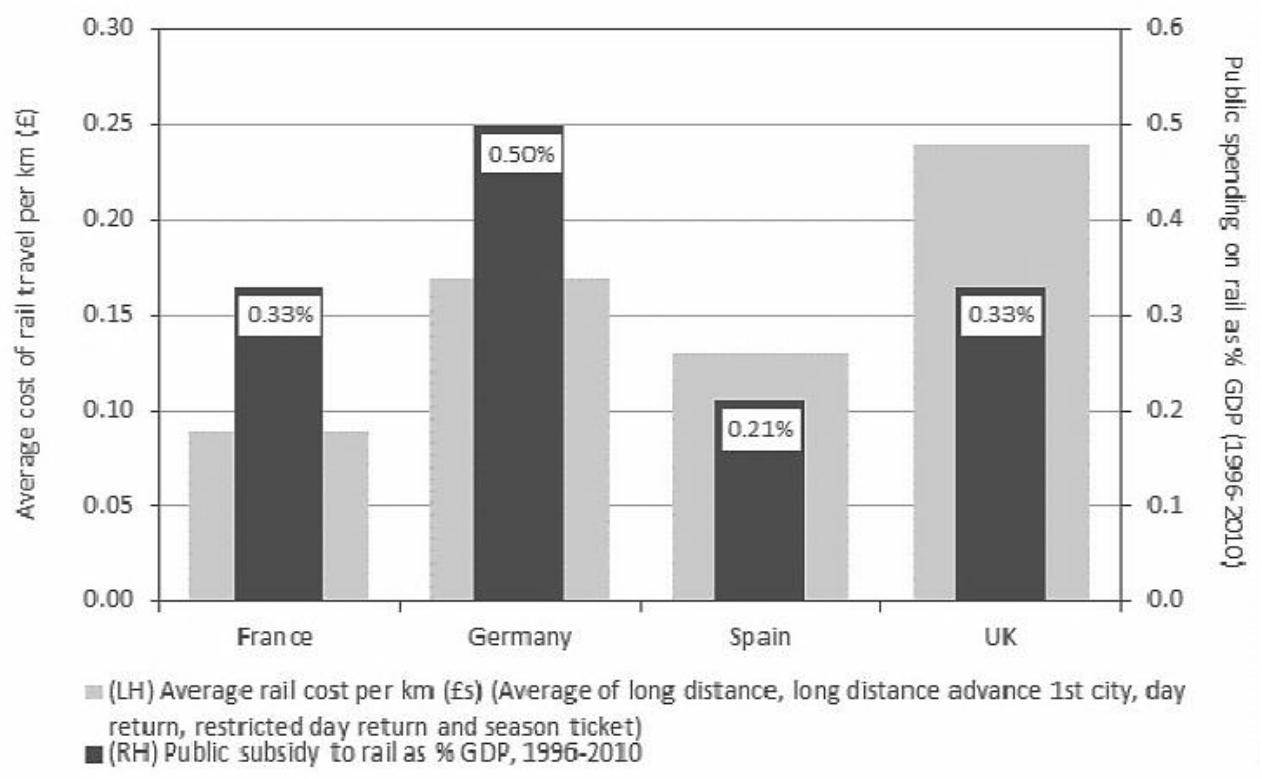

Fig. 2 - Comparativa del coste medio del precio del viaje por $\mathbf{k m}$ en la industria del ferrocarril, así como el porcentaje de subsidio recibido en Francia, Alemania, España y Reino Unido por parte del Gobierno (Bowman et al., 2013)

Comparando Reino Unido con Alemania, es razonable pensar que los bajos precios en la segunda pueden ser consecuencia de los altos subsidios que recibe el sector. Sin embargo, en Francia, con el mismo ratio de subsidio, el coste medio del viaje por kilómetro es mucho menor que en Reino Unido. Preston (2009) afirma que el aumento de las tarifas de larga distancia fue causado por las mejoras en la gestión de las técnicas de mantenimiento desde el fatídico accidente de Hatfield.

Glaister (2004), por su parte, compara el papel que juega el gobierno en la regulación de los servicios ferroviarios con la de otros sectores británicos liberalizados. Mientras en otra 
industria el rol del gobierno se centra en otorgar las licencias a los operadores, en el sector ferroviario el principal objetivo es la regulación económica, y la formulación de cánones para el uso de la plataforma. Glaister (2004) subraya que esta regulación de las tarifas se realiza a través de los contratos para las TOC, que tienen una implicación directa en las subvenciones y, por lo tanto, en el gasto del gobierno.

\section{CONCLUSIONES}

Derivadas de la lectura anterior, es posible extraer dos conclusiones principales: la primera, la actuación del Estado en el caso de privatización inglés no fue suficiente, ya que el único beneficio obtenido fue el incremento del número de viajeros, hecho que, además, pudo tener su causa en otros factores; la segunda, la aplicación de una correcta regulación tarifaria es indispensable tanto para la gestión de la demanda, como para el control del déficit público.

Consecuentemente, el aprendizaje para el caso análogo español se fundamenta en dos recomendaciones: en primer lugar, la fragmentación en la provisión de un servicio público a nivel nacional no es sinónimo de mejora; en segundo lugar, a pesar de existir diversas teorías que tratan de mitigar los fallos de mercado, en el caso del transporte ferroviario la experiencia demuestra que la intervención directa del Estado es imprescindible para garantizar el bienestar de la sociedad. En ese sentido, la posición de partida en España en cuanto a la administración de la infraestructura resulta favorable, pues ADIF es una entidad pública que no será liberalizada.

Si bien es cierto, a priori, las posibilidades de éxito del proceso liberalizador en España son limitadas si se considera la notable diferencia existente entre la demanda de movilidad española y la inglesa (muy superior), además de la permanencia en el mercado del operador público, pues si mantiene los mismos surcos ferroviarios en su servicio sobre las líneas liberalizadas, el operador privado contará con un reducido margen de maniobra.

\section{AGRADECIMIENTOS}

Los autores agradecen al Vicerrectorado de Investigación, Desarrollo e Innovación de la Universidad de Alicante la concesión de las ayudas enmarcadas en el Programa Propio para el fomento de la I+D+i, cuya beneficiaria es la coautora Patricia Fernández Aracil.

\section{REFERENCIAS}

BECKERS, T., HIRSCHHAUSEN, C., HAUNERLAND. F., y WALTER, M. (2009). LongDistance Passenger Rail Services in Europe: Market Access Models and Implications for Germany. International Transport Forum, Madrid.

BOWMAN, A., FOLKMAN, P., FROUD, J., JOHAL, S., LAW, J., LEAVER, A., MORAN, M. y WILLIAMS, K. (2013). The great train robbery: rail privatisation and after. Centre for Research on Socio-Cultural Change (CRESC), Manchester, pp. 1-167.

BOWMAN, A. (2015). An illusion of success: The consequences of British rail privatisation. 
Accounting Forum, 39, pp. 51-63.

CAMPOS, J. (2015). La competencia en el ferrocarril: un análisis del nuevo marco institucional en Europa y en España. Fedea Policy Papers, 2015/12, pp. 12-19.

CROMPTON, G. y JUPE, R. (2003). Such a silly scheme: The privatisation of Britain's Railways 1992-2002. Critical Perspectives on Accounting, 14, pp. 617-645.

DEPARTMENT FOR TRANSPORT y OFFICE OF RAIL REGULATION (ORR). (2011). Realising the Potential of GB Rail. Final Independent Report of Rail Value for Money Study. DREW, J. (2006). Rail Freight: the Benefits and Costs of Vertical Separation and Open Access. Association for European Transport Conference.

GIBB, R., LOWNDES, T. y CHARLTON, C. (1996). The privatization of British Rail. Applied Geography, 16(1), pp. 35-51.

GLAISTER, S. (2004). British rail privatisation: Competition destroyed by politics. University of Bath School of Management, Bath, Occasional Paper 23.

GÓMEZ-IBÁÑEZ, J. A. (2006). An overview of the options. En: J.A. GÓMEZ-IBÁÑNEZ y G. de RUS (eds.), Competition in the railway industry. An international comparative analysis. Edward Elgar, Cheltenham, pp. 1-24.

KNOWLES, R.D. (2004). Impacts of privatising Britain's rail passenger services franchising, refranchising, and Ten Year Transport Plan targets. Environment and Planning, 36(11), pp. 2065-2087.

NASH, C. A. (2000). Privatization and Deregulation in Railways: An Assessment of the British Approach. En: B. BRADSHAW y H. LAWTON SMITH (eds.), Privatization and Deregulation of Transport. Macmillan Press Ltd., London, pp. 159-176.

NASH, C.A. y SMITH, A.S.J. (2006). Passenger rail franchising: British experience. ECMT Workshop on Competitive Tendering for Passenger Rail Services, Paris.

PRESTON, J.M. (2009). Competition for long distance passenger rail services: The emerging evidence. 18th International Symposium on Transport Economics and Policy, Madrid.

PRESTON, J. y ROBINS, D. (2013). Evaluating the long term impacts of transport policy: the case of passenger rail privatisation. Research in Transportation Economics, 39, pp. 1420 .

TRIBUNAL DE CUENTAS. (2015). N 1090 Informe de fiscalización de la financiación de las infraestructuras ferroviarias en el período 2011-2013. 